\title{
How well are we managing E-waste in India: evidences from the city of Bangalore
}

\author{
Anwesha Borthakur $^{1} \cdot$ Madhav Govind $^{1}$ \\ ${ }^{1}$ Centre for Studies in Science Policy, Jawaharlal Nehru University (JNU), New Delhi 110067, India
}

Received: 15 January 2017/Revised: 17 May 2017/ Accepted: 26 May 2017/Published online: 28 June 2017

(c) Joint Center on Global Change and Earth System Science of the University of Maryland and Beijing Normal University and Springer-Verlag GmbH Germany 2017

\begin{abstract}
As a toxic waste stream, E-waste poses serious challenges to the waste management initiatives in India. While the hazardous components of E-waste call for environment-friendly disposal mechanisms, the valuable and precious metal constituents necessitate adequate infrastructural provisions and responsible management programmes to avoid the loss of economically vital materials. Considering this duality, this paper is an attempt to evaluate the current E-waste disposal practices in India, particularly emphasizing on the city of Bangalore. Three sectors listed as 'bulk consumers' of electrical and electronic equipments under the recent E-waste (Management) Rules, 2016, namely (1) IT and electronics, (2) banking and (3) education, are considered for the study purpose. Our experience suggests that these bulk consumers adopt two different approaches to comply with the new EPR guidelines as enlisted in the E-waste (Management) Rules, 2016. These are: (1) IT companies like Wipro adopts a 'take-back system' where it is responsible for taking back the products originally produced in its various facilities from the consumers; (2) most of the banks and educational institutes take 'auction' as the measure by calling tenders from authorized E-waste recyclers with some banks embracing an 'E-waste exchange system', or complying through producer responsibility organizations (PROs) for responsible E-waste management in the city. However, we sense a lack of meticulous initiatives towards addressing the E-waste crisis largely prevalent across these sectors. We
\end{abstract}

Anwesha Borthakur

anwesha227@gmail.com

Madhav Govind

mgovind11@gmail.com argue that ensuring responsible disposal behaviour is central in any successful E-waste management initiative. Further, we emphasize on the relative disinterestedness of the research community in addressing the issues concerning E-waste in India by carrying out a detailed bibliometric analysis on the topic. We conclude that a transparent system across these diverse sectors with adequate infrastructural provisions and administrative controls is the key to address India's E-waste apprehensions.

Keywords E-waste - Disposal behaviour - Bangalore - IT · Banking sector

\section{Introduction}

The considerable rise in the volume of waste generated is a critical issue accompanying global developmental paradigm. In the absence of adequate infrastructural provisions in the developing world, rapid rate of population growth and urbanization processes make municipal solid waste (MSW) management a demanding task (Yadav et al. 2016). Further, resulting in an exponential increase in the E-waste generation, the new millennium has observed an increasing demand and proliferation of electronic equipments (Morris and Metternicht 2016). Globally, electronics is recognized as the largest, most affluent and high-technology industry with the greatest 'value-adding' prospective responsible for changing the social and economic landscape (Zeng and $\mathrm{Li}$ 2016). Accordingly, the problem of MSW management has been intensified manifolds with the advent of E-waste from obsolete electrical and electronic equipments (EEEs). E-waste requires special collection and handling 
considerations. Apart from its domestic generation, India receives large volumes of illegally imported E-waste. Majority of the E-waste in the country is handled by the informal workshops due to the availability of cheap labour and absence of governmental regulations or associated errors in implementation (Awasthi et al. 2016a, b).

In India, E-waste has become an important waste stream in terms of its volume and toxicity. It is a complex category of hazardous waste. It contains considerable portions of heavy and precious metal components and persistent organic pollutants (POPs). While toxic components of E-waste pose serious threats to the human health and environment (Garlapati 2016), precious metal components provide sufficient incentives for recycling. This is particularly true in the context of the urban poors in the developing world. This duality emphasizes the need towards a careful E-waste management system from both economic and environmental perspectives (Tran et al. 2016). For instance, enhancing the significance of recycling, valuable metals in E-waste include iron, copper, aluminium, cobalt, nickel, tin and zinc and precious metals include gold, silver and palladium (Alsheyab 2015). Thus, E-waste calls for sustainable management practices which are fundamental in preventing the loss of economically important materials and to alleviate the emergent scarcity of resources (Van Eygen et al. 2016). For example, the dearth of landfill sites has stimulated alternative waste management techniques through technological innovations in the European Union (EU) for solid waste and encouraged source reduction and recycling approaches ( $\mathrm{Li}$ et al. 2015).

Some fundamental information on E-waste, including its generation amount, composition and resource transfer, is essential in both the recycling industry and formulating government policies (Zeng et al. 2016b). However, obtaining such effective information remains a challenge because of two key reasons. Firstly, developing countries lack a comprehensive E-waste inventory with crucial statistical data on production, sales, trade of EEEs and also lack adequate information on the formal E-waste management system. Secondly, the unregistered infiltrations of EEEs into the domestic market or E-waste stream exclusive of any administrative check (Tran et al. 2016) which need adequate addressing. Zeng et al. (2017) had proposed that E-waste management should be addressed at three different levels: (1) microscopic (substance), (2) mesoscopic (material) and (3) macroscopic (product and component). As approximately $100 \%$ of the globally mined indium, $44 \%$ of the copper, $72 \%$ of the ruthenium, $34 \%$ of the silver, $50 \%$ of the tin and $22 \%$ of the mercury every year are used by the electronic and electrical industries, recycling of E-waste has the potential to contribute significantly towards conservation of valuable resources and sustainable energy utilization (Zeng et al. 2016a).
Responsible E-waste disposal behaviour of consumers and their awareness are central in any effective E-waste management initiatives (Borthakur and Singh 2016). For instance, Awasthi et al. (2016c) argue that informal E-waste recycling activities and open dumping of E-waste must be substituted by the best available technology and environmental practices through appropriate monitoring and regular awareness programs for residents and workers. Unfortunately, India still lacks a conscientious group of people in its both urban and rural areas involving in sustainable E-waste management practices. E-waste management in the country has been a tedious and challenging task due to its diverse cultural, economic, societal, environmental and other such considerations. For instance, because of the peculiar nature of recycling market in India, where consumers await some monetary returns while disposing of their E-waste, the extended producer responsibility (EPR) model widely practiced in the developed world is prone to failure in the country (Dwivedy et al. 2015). Such distinctive consumers' behaviour encourages the growth of a large informal E-waste recycling sector in India which processes E-waste mostly by using rudimentary techniques and unskilled labours (Pandey and Govind 2014).

Thus, in developing countries, informal scrap networks have historically generated income by collecting, extracting and selling recyclable materials, thereby playing an important role in solid waste management (Davis and Garb 2015). In the context of India, for instance, Ghosh et al. (2016: 694) argue, 'the material flows from waste imports not only offer a business opportunity, but also satisfy the demand for cheap second-hand electrical and electronic equipment, which also provides material to informal and semi informal sectors for processing'. Due to the financial incentives involved, 95\% of E-waste in India is recycled informally which has the potential to be overwhelmed soon (Kannan et al. 2016). Further, there is an omnipresent ambivalence among Indian citizens regarding responsible E-waste disposal (Borthakur and Singh 2017). In the absence of adequate information dissemination mechanisms, people are largely unaware about the disposal processes and initiatives undertaken by the local or state governments. Consequently, majority of E-waste, amounting for $75 \%$ or more, is kept stored across various organizational structures, businesses, households and so on in India (Ramachandra and Varghese 2004; Borthakur 2014).

Considering the complexities in E-waste management system in India, this paper is an attempt to evaluate the current E-waste disposal status in the country with special focus on the city of Bangalore. The case study carried out with some 'bulk consumers' in Bangalore is considered in order to provide first-hand information about the current 
E-waste management system and its associated repercussions.

\section{Inadequate addressing of E-waste in India}

E-waste in India is an issue which is yet to be addressed adequately by the research community, academics, policymakers, government and non-governmental organizations and so on. For instance, unlike Guiyu, the largest E-waste recycling site in China or Taizhou, the second largest one or Agbogbloshie, Ghana, E-waste recycling hubs in India attract not as much research and policy interest from the international community as the Chinese or Ghanaian hubs do (Borthakur and Singh 2016). Therefore, in order to evaluate the current status of E-waste research in India and compare it with the international scenario, a bibliometric analysis has been carried out in the 'Scopus' database using the search query: (TITLE-ABS-KEY (('E-waste' or 'Electronic Waste' or 'WEEE' or 'Waste Electrical and Electronic Equipment'))).

The search results in 4201 research documents published during the 30-year period from 1986 to 2016. Starting with only two research papers published in 1986, the research on the topic gained momentum from the year 2004, publishing more than 100 papers since the year 2004 and 200 papers each year ever since 2008. Signifying growing interest in the research community, the year 2015 has observed 518 research documents published on the topic in a single year (see Fig. 1).

However, the country-wise distribution of E-waste research shows that researches on the topic are largely concentrated only in a few countries, particularly in the People's Republic of China (see Fig. 2). While China

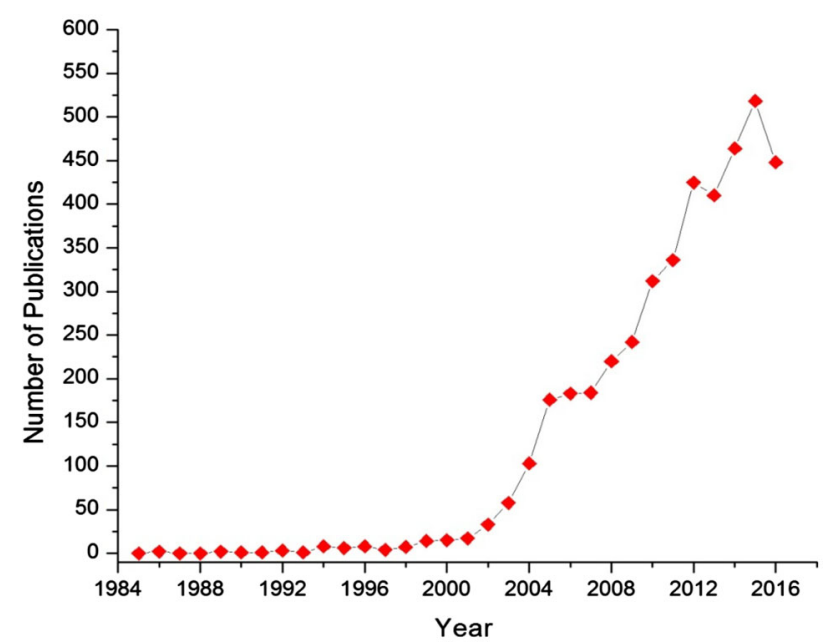

Fig. 1 Year-wise distribution of E-waste research. Source Scopus, 2016

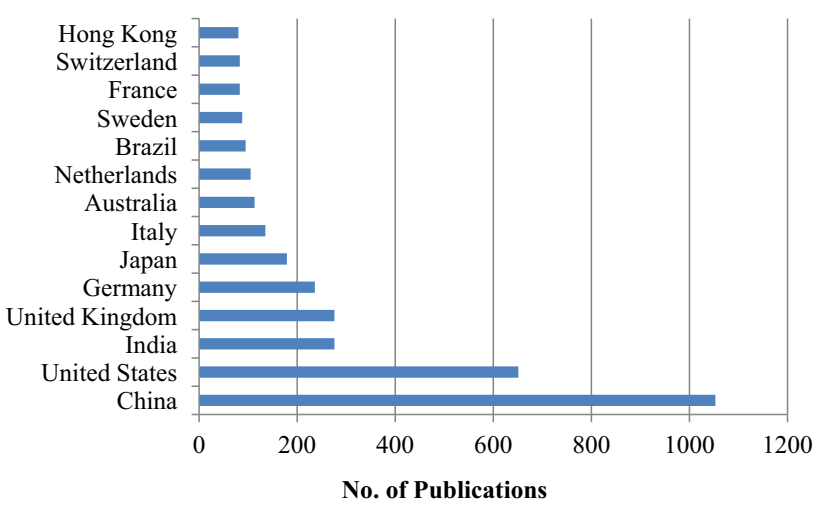

Fig. 2 Country-wise distribution of E-waste research. Source Scopus, 2016

produced 1053 research documents during this 30-year period from 1986 to 2016, the second ranked the USA produced little more than half of what China produced with 651 research documents. India and the UK stand joint third in the ranking, producing 276 scientific documents each. Although China and India share a lot in common with respect to E-waste and associated concerns, India's research share on the topic is far lesser than that of China. Not a single research institute in India has been enlisted in the name of institutes producing 15 or more research papers during this 30-year period on E-waste-related topics (see Fig. 3 for the list of institutes producing 30 or more research papers from 1986 to 2016). Indian Institute of Technology, Delhi (IIT-D), produced highest 11 research papers on the topic among all Indian research institutes.

Different institutes under the Chinese Academy of Sciences, Tsinghua University, Shanghai Jiaotong University, Hong Kong Baptist University are considerably visible in the global E-waste research scenario. The relative disinterestedness of the research community in addressing the issues concerning E-waste adequately and effectively in India has encouraged us towards exploring this emerging concern so that appropriate policy instruments could be devised and management strategies could be formulated.

\section{E-waste rules in India: some insights}

Formulation and implementation of appropriate legislations are fundamental for sustainable management of E-waste. Global, regional and national legislations could facilitate eco-design and aid in saving resources, emission reduction, eradication of the toxicity, etc. (Awasthi et al. 2016a). For the first twenty years of the economic liberalization in India, E-waste observed no significant hindrance in its expansion. This period ensured increasing penetration of EEEs into the market due to the evolution of 


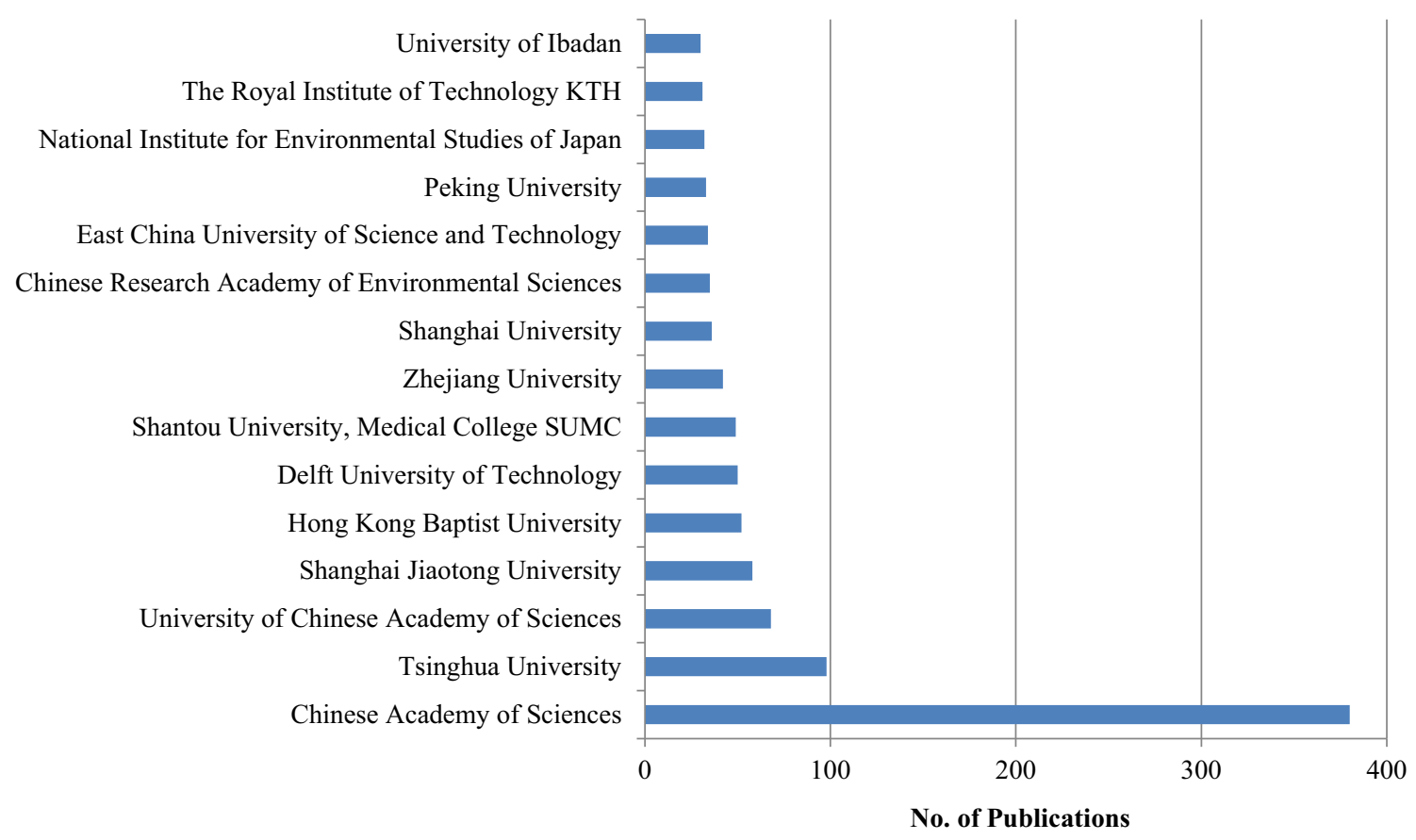

Fig. 3 Affiliation-wise distribution of E-waste research. Source Scopus, 2016

the IT and electronics sector. For most part of these years, E-waste was an unnoticeable and silent stream of waste observing a remarkable growth in the country. The E-waste (Management and Handling) Rules, 2011 was the first legal initiative formed to exclusively address the E-waste management concerns in India. Thus, although the IT revolution started in India way back in early 1990s, a proper policy related to E-waste was being introduced almost after 20 years in 2011 (Borthakur 2015). This rule primarily emphasized on the extended producer responsibility (EPR) model for effective channelization of E-waste to the registered collectors/dismantlers/recyclers. The Organization for Economic Cooperation and Development (OECD) defined EPR as 'an environmental policy approach in which a producers' responsibility for a product is extended to the post-consumer stage of a products life cycle including its final disposal' (Widmer et al. 2005). Within the purview of the 2011 rules, producers of EEEs or any other person/agency/association can set up collection centres intended for the collection of E-waste. This means that the EPR was not the sole responsibility of the producers and there were scopes of loopholes to avoid the burden to E-waste management by them. Thus, principles of EPR have the potential to be desecrated by not maintaining the exclusivity of producer's responsibility towards collecting the E-waste produced from their electrical and electronic products.

The recent E-waste (Management) Rules, 2016 provides a number of stringent yet insightful amendments to the previous rules. For instance, the collection of E-waste is now exclusively made a producer's responsibility, which can set up collection centre or point or even can arrange buy-back mechanism for such collection (MAIT 2016). If the responsibility of collection of E-waste is provided to a dealer on behalf of the producer, it requires the dealer to collect the E-waste by 'providing the consumer a box, bin or a demarcated area to deposit e-waste, or through takeback system and send the e-waste so collected to collection centre or dismantler or recycler as designated by producer' (MoEF 2016: 7). But eventually producers are the ones who are entirely accountable for the waste produced by their obsolete EEEs. A target-based collection approach has been introduced within these rules. The phase-wise targets are: (1) $30 \%$ (either by number or by weight) of the quantity of waste generation during the first two years of implementation of rules, (2) $40 \%$ during third and fourth years, (3) 50\% during fifth and sixth years and (4) $70 \%$ during seventh year onwards (MoEF 2016: 22).

On a positive note, 'Deposit Refund Scheme' has been introduced as an additional economic instrument within the purview of this 2016 legislation. As defined in the rules, 'deposit refund scheme means a scheme whereby the producer charges an additional amount as a deposit at the time of sale of the electrical and electronic equipment and returns it to the consumer along with interest when the endof-life electrical and electronic equipment is returned' (MoEF 2016: 2). Further in order to ease of implementation of EPR by producers, options in the form of additional channels such as setting up of PROs, E-waste exchange and E-retailer are provided for to ensure efficient 
channelization of E-waste. The horizon of EEEs brought under this rules is also expanded by the addition of a few more electrical/electronic items, so thus the definition of 'bulk consumers'. For instance, compact fluorescent lamp (CFL) and other mercury containing lamps are brought under the purview of these rules.

'Bulk Consumer' is being redefined by the addition of 'healthcare facilities' which have turnover of more than one crore or have more than twenty employees. Nevertheless, categories of EEEs covered under this rule are still insufficient as compared to its European counterparts. While the Indian rules list only two categories of EEEs ('Information technology and telecommunication equipment' and 'Consumer electrical and electronics'), European Union's (EU's) WEEE Directive (2003) has included ten categories of EEEs with the 11th category supposed to be incorporated from 2019. Only 21 varieties of EEEs are included within the two defined categories in India. However, a wide array of EEEs is included within the ten categories under EU's directive which amount for several folds as compared to the Indian list. Such a comprehensive inclusion of EEEs is essential for holistic addressing of the E-waste management issues in India.

The success of any legislation depends on its diffusion and execution up to the grassroots level. Considering the dissemination of EEEs in every strata of the society in both urban and rural India, the challenge today within the realm of the policy community lies in the successful implementation of E-waste (Management) Rules, 2016. This requires adequate awareness among the diverse 'bulk' and 'individual' consumers about the disastrous health and environmental consequences of negligent E-waste disposal practices.

\section{The case study}

\subsection{The study area}

In an attempt to assess the intensity of E-waste management challenges in India, a primary investigation was carried out at the city of Bangalore in the state of Karnataka. As per provisional reports of Census India, 2011, the population of Bangalore was 8,443,675 with an average literacy rate of $88.71 \%$ (Census 2011). The city of Bangalore is known for housing a number of information technology (IT) and electronics companies which contributes significantly to the city's economy and earns the city the title as the 'Silicon Valley of India'. Nearly, all the major IT firms of the Europe and the USA have set up their research and development $(\mathrm{R} \& \mathrm{D})$ centres and software development facilities in Bangalore (Patibandla and Petersen 2002). The Indian government's catalytic role in establishing the first software technology park in Bangalore in 1990 has played a pivotal role in the growth of the IT industry to Bangalore. The region in and around Bangalore already had a significant presence in the public sector manufacturing industries and laboratories such as telecommunications, aerospace and defence electronics among others which provided the necessary infrastructures and skill advantages for the further development of the city's IT and electronics sector (Parthasarathy and Aoyama 2006). Consequently, apart from being a base for major Indian IT service providers such as Wipro, Infosys, Tata Consultancy Services (TCS), Tech Mahindra and HCL Technologies, the city became a preference for a large number of multinational companies seeking to establish their offshore development centres within India.

Further the state of Karnataka could be arguably called the cradle of banking sector in India. Seven of India's leading banks-Canara Bank, the State Bank of Mysore, Corporation Bank, Syndicate Bank, Karnataka Bank, Vijaya Bank and Vysya Bank-started off from the state (Sharma 2005). Among them, Canara Bank, the State Bank of Mysore, Corporation Bank and Vysya Bank have their headquarters in the city of Bangalore. The emergence of the IT sector further boosted the growth of the city's banking sector with many international and national banks establishing their branches and offices in the city.

Bangalore houses a good number of premier educational institutes in the country. Apart from the presence of several domestically well-known management, science and technology and law institutes, the city has internationally acclaimed institutes like the Indian Institute of Management (IIM Bangalore), Indian Institute of Science (IISc), Tata Institute of Fundamental Research (TIFR-Centre for Applicable Mathematics), National Law School, The National Institute of Mental Health and Neurosciences (NIMHANS), Institute for Social and Economic Change (ISEC), International Institute of Information Technology (IIIT) and so on. The presence of these leading educational institutes essentially provided the necessary human resources to the IT sector during its formative years which has been continuing till date. Describing the role of the city's education sector on its development as an IT hub, Joshi (2014) states, 'Bangalore was known till the '70s as the destination of public sector industries. In the ' 80 s and ' 90 s, it donned the role of producer of quality engineering, medical and management graduates. In the '90s, with economic liberalization and development of information technology and IT-enabled services in India, Bangalore took centre-stage and emerged as the IT destination of India'. ${ }^{1}$

\footnotetext{
${ }^{1}$ See: http://timesofindia.indiatimes.com/home/education/news/Whatmakes-Bangalore-an-education-hub/articleshow/35613634.cms.
} 
The presence of these prominent sectors provided adequate validation for considering Bangalore for our study purpose. Further, the city ranks third in the E-waste generating cities in India (MoEF 2008). Electronic City Industrial area in Bangalore hosts a significant majority of IT companies and is therefore a source of sizable amounts of E-waste. An estimated 30,000-40,000 computers become obsolete every year from the IT industry in Bangalore alone. Home to more than 1200 foreign and domestic technology firms, Bangalore figures prominently in the danger list of cities faced with an E-waste hazard (Needhidasan et al. 2014). Again, as a rapidly educational and commercial hub of the country, Bangalore has sizable EEE user base. Therefore, it has a potential to act as a model city to evaluate the problems associated with E-waste in major urban centres in India.

The study was carried out at three different sectors, namely (1) information technology (IT) and electronics, (2) banking sector and (3) educational institutes. All these sectors are 'bulk producers of E-waste' in India (MoEF 2008, 2016) and thus require adequate addressing towards responsible management of E-waste in the country. While selecting the study samples, key representatives under each category are tried to be included. For instance, regarding the banking sector, the first five banks (see Table 1) represent major 'public sector' banks present in the city with headquarters of Canara Bank and the State Bank of Mysore situated in Bangalore. The next three represent prominent 'private sector' banks, and the last two represent 'cooperative' banks. The third largest IT company in India, Wipro, ${ }^{2}$ was considered as a major representative from the IT sector. Similarly, Indian Institute of Management, Bangalore (IIM-B), was considered as the key representative of the educational sector in the city.

\subsection{Methods and execution of the survey}

Both primary and secondary sources of data were evaluated to assess various E-waste-related issues such as its generation, management strategies, disposal behaviour, publics' perception/awareness and so on. Secondary resources include journal and newspaper articles, books, annual reports of various key representatives, blogs and other internet resources. An empirical study was conducted with the 'bulk consumers' of EEEs in the city of Bangalore in order to evaluate the existing E-waste management structures, consumers' disposal behaviour and associated awareness. Obsolete 'computers' were considered as the representative of E-waste because it is the most prominent category of E-waste in the sectors considered for our study

\footnotetext{
2 http://www.Wipro.com/documents/The-Financial-Express-changemanagement-a-hurdle-in-way-of-automation.pdf.
}

purpose. Further, a recent study by the Associated Chambers of Commerce and Industry of India (ASSOCHAM) revealed that computer equipments contribute up to $70 \%$ of the total E-waste generation in India. ${ }^{3}$

Semi-structured interview methods were carried out with representatives from the three sectors mentioned in the previous section. A basic questionnaire was prepared for the selected sectors (see Table 2). For these face-to-face interviews, all the questions were not designed or phrased in advance. Some of the questions were shaped during the interview, letting both the interviewer and the person being interviewed the flexibility to explore in detail or discuss relevant issues. While interviewing, the questions were also modified according to the response of the person being interviewed and needs of the sector involved. Thus, semistructured questionnaire method was selected to collect data because it provides the interviewer flexibility to add, modify and omit questions during the time of the interview. As E-waste management in India is reasonably an unexplored area of research, such kind of flexibility is indispensable for gathering reliable and purposeful data.

The interviews were informal and carried out with relevant stakeholders such as IT professionals and administrative staffs of academic institutes/banks to have their responses on E-waste management practices in their respective institute. Informal or conversational interviews allow the interviewer to converse and probe emerging concerns, or ask questions, in a naturalistic manner, on atypical events. The nature of such kind of interview technique is 'casual', and thus, it has the potential to be helpful in drawing highly candid accounts from the respondents (Reeves et al. 2008). Overall, the study was essentially qualitative in nature with an aim to express the views and voices of the associated stakeholders.

While collecting information, prior attention was given to the specific requirements of the sector concerned. For instance, we were aware that being high security zones, entry to the IT and electronics companies in Bangalore would be highly restricted. Therefore in this sector, prior appointments through e-mail were taken by contacting the concerned officers/staffs dealing with E-waste/sustainability issues in the company. Although we attempted to get in touch with a number of such companies, only a handful of them provided us access to collect relevant information on their E-waste management practices and preferences. As our attempts to take prior appointments in the banking and educational sector resulted in no substantial success, we therefore chose to directly visit some of the representative institutes under each category. The largest branch or the head office of the respective bank was tried to be visited. Mostly, we interacted with persons from the IT department

\footnotetext{
${ }^{3} \mathrm{http} / / / \mathrm{www}$.assocham.org/newsdetail.php?id=5725.
} 
Table 1 The bulk generators of E-waste considered for the study purpose

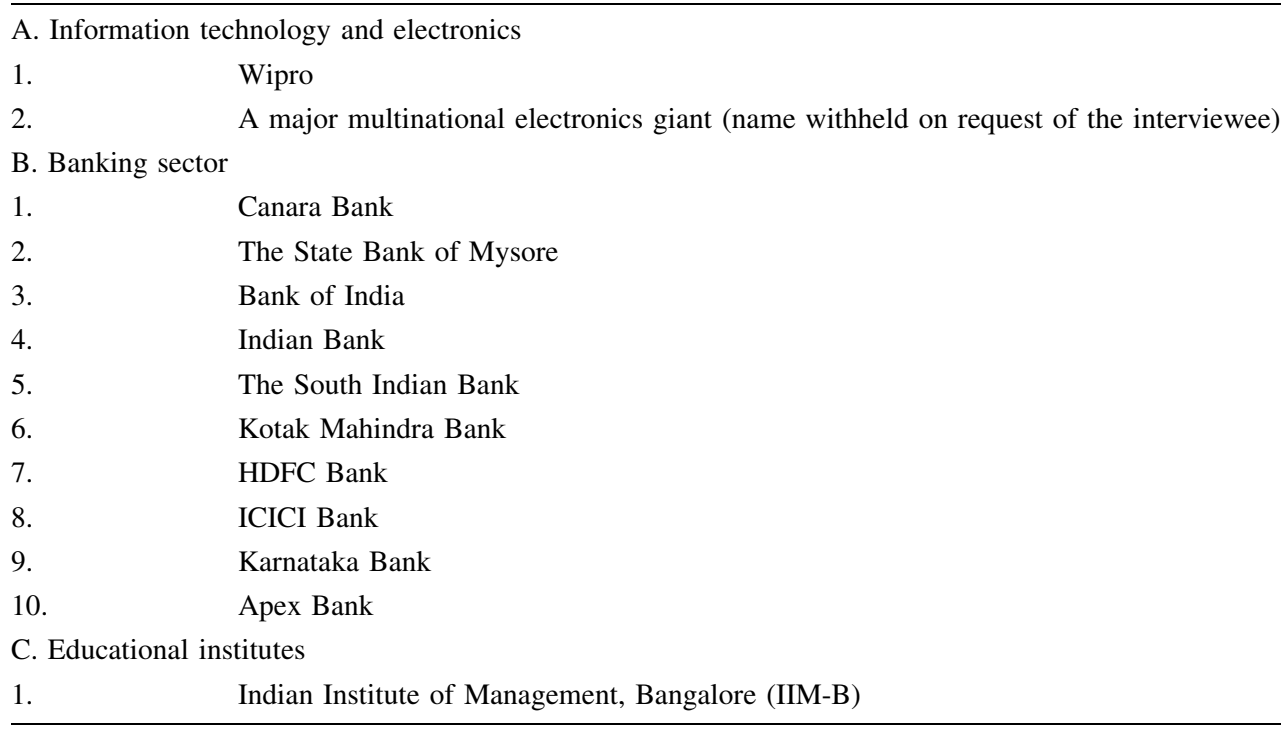

in these banks and educational institutes and tried to gather purposeful information related to the procurement of electronic items and disposal policy of E-waste in their organization.

We also analysed the available E-waste management policies of these organizations accessible through the host websites. A number of policy documents on E-waste management initiatives, such as that of Wipro, were evaluated. Further, the compliance of the management initiatives of different sectors especially to the E-waste management (Management and Handling) Rules, 2011 and the E-waste (Management) Rules, 2016 was critically examined. Nevertheless, it has been a challenge to collect relevant data from these sectors regarding their E-waste management practices. During direct approaches to the banks and educational institutes, getting permission to inter the vicinity of such institutes and meeting the concerned representative having knowledge about their E-waste management procedures were major challenges. Language was another barrier in conveying the purpose of our visit to the concerned authority through the security stuffs present at the gate who mostly spoke the vernacular language.

Further complicating our challenges, barring a few, there was an inherent reluctance among the representatives from each sector towards providing necessary information on their E-waste management processes. Even after repeated attempts through visits, e-mail and phone calls, a good number of major IT and electronics companies, educational institutes and popular public and private sector banks did not either reply back or disclose any information on their current E-waste management practices.

\section{Results and discussion}

\subsection{Current disposal practices and policies at the IT and electronics sector}

Necessitating effective implementation of responsible management strategies, the result of our study reflects that

Table 2 Some of the representative questions from the semi-structured questionnaire

1 What is the average life of the computers at your institute?

2 Who is responsible for maintenance of the computers in your institute? Is it the dealer from whom computers were purchased or somebody else?

3 Do you maintain 'Annual Maintenance Contract' or any such agreements with anyone towards maintenance of your computers and related equipments?

4 How do you usually discard your outdated or unused computers and related equipments?

5 Who decides the process of discarding of the computers and related electronics?

6 Do you discard your obsolete electronics by giving them to the scrap vendors at a certain price?

7 Does your institute have an E-waste management policy?

8 What steps do your institute takes to comply with 'the E-waste (Management and Handling) Rules, 2011'? 
today, E-waste generated in each of the three sectors are increasing at a fast pace. For instance, IT giants such as Wipro takes up a 'Tech Refreshing' approach every 3-4 years, where a lot of EEEs are declared obsolete and thus are being disposed off. Due to the rapid progress in the area of IT and electronics, newer and modified versions of software are introduced every few months. Mostly, older hardware is not compatible with the new software and purchase of a new device appeals more to the owner over modification of the older devices. A number of our respondents pointed out that considering the cost of modification or repair and the uncertainty involved thereafter, it is wiser to purchase a new device with a warranty period than modifying or repairing the older electronics.

On its customers' front, Wipro has an effective takeback programme wherein it had collected 241 tons of E-waste in 2010-2011 and 247 tons in 2012-2013 with a target of $100 \%$ recycling of E-waste through prescribed methods by 2014-2015. Subsequently, the total volume of E-waste collected and recycled through authorized vendors in 2014-2015 was a significant 317 tons. ${ }^{4}$ This E-waste also included some non-Wipro products sold as a part of integrated IT services projects. The gradually increasing volume of E-waste collected by Wipro is a positive contribution towards India's sustainable E-waste management initiatives. All the E-waste collected by this IT giant is recycled by authorized recyclers. Wipro engages closely with government on E-waste policy advocacy, both through industry networks and direct contacts. For instance, Wipro was a convener of the working group of the Confederation of Indian Industry's (CII) Environment committee on E-waste whose goal was to bring producers, customers, recyclers and government together to a common platform in order to discuss improvements in the E-waste (Management and Handling) Rules, 2011.

It has been observed that at institutional levels of IT and electronics sector, there are provisions to address the E-waste generated by their own facilities. For instance, Wipro's waste management strategies are centred on either (1) recycling the waste for further use or (2) arranging for safe disposal. ${ }^{5}$ Wipro pursues rigorous waste management processes by segregating waste into various categories such as inorganic, organic, hazardous, biomedical, E-waste and packaging in order to operationalize its waste management strategies. These diverse categories of waste are subsequently either recycled internally in its in-house facilities or outsourced through vendors. Wipro provides the

\footnotetext{
${ }^{4}$ Wipro Sustainability Report, 2014-2015 available at http://wipro sustainabilityreport.com/14-15/Sustainability-Report-with-special-14-15. pdf.

${ }^{5}$ Wipro Annual Report, 2015-2016 available at http://www.wipro. com/microsite/annualreport/2015-16/natural-capital.html.
}

responsibility of sustainable E-waste management to the 'Central Material Facility' of the company.

Wipro maintains a mass-balance report where E-waste recyclers have to report back to the company about the procedures adopted to dispose of the collected obsolete EEEs. In detail, reporting on the treatment and disposal mechanisms for hazardous and non-hazardous components of E-waste is a compulsory practice. The company seeks proof of the disposal procedures that the recyclers claim to adopt and thus cross-checks the data provided by the recyclers. Wipro even has its own recycling facility in the city of Bangalore to promote recycling of obsolete lamps. In its recycling facility, heavy metals present in waste lamps are segregated and reused. Mercury, present in the lamp, is usually distilled and then used again.

Wipro has collaborated with Electronic Light Manufacturing Association, Bangalore, for responsible disposal and recycling of waste lamps. In collaboration with an Australian NGO, InfoActiv, Wipro assisted in creating a common platform for responsible E-waste management in the Electronic City Industrial area in Bangalore. This area hosts the majority of IT companies in the city and thus produces considerable volume of E-waste. InfoActiv is considered a major organization with key focuses on E-waste. The platform provided by the Wipro-InfoActiv collaboration aids in streamlining the processes for E-waste management from the bulk consumers. Wipro is currently working on an E-waste programme for the Electronics City Industrial Township Authority (ELCITA) cluster. Further Wipro continues to be a part of the subcommittee on 'Waste' in the CII National Environment Committee.

Unlike Wipro, a talk with an official of a major global electronics giant (name withheld to secure the identity of the interviewee) provided a different picture. For instance, a major concern for the electronics company is the disposal of mobile phones meant for 'trial' purposes. Average 4-5 trials per month are carried out in different facilities of the company which involve the use of a large amount of trial mobile phones. In order to avoid duplication by the competitors and other market-related concerns, these trial phones are disposed off and subsequently destroyed in bulk once testing and experimentation are completed. As per the information provided, the mobile phones (and cameras) are just taken to landfill sites and crashed with the help of crashing machines or vehicles. This activity is carried out in direct supervision of the concerned company's authorized persons in order to avoid any manipulation or loopholes. In most of the cases, these are high-definition phones eventually attracting high prices in the market. The person interviewed revealed that he had around 70-80 trial mobile phones under his control alone. Considering the size of the company and the number of people engaged in testing activities, it could be postulated that huge quantities of 
waste phones are produced in different facilities of the company in different Indian cities. However, mobile phones are not the only equipment that undergoes such a procedure. It is applied to many other EEEs before eventually finding its way to the market.

On a positive note, both Wipro and the electronic company considered provide their employees the facility to drop off their E-waste in specified bins situated inside the company's premises. However, a discussion with a number of employees shows that they do not have much idea regarding the whereabouts of the obsolete EEEs once they are discarded in those bins.

\subsection{Current disposal practices and policies at the banking and educational sector}

Regarding the E-waste management practices in the banking sector, popular public sector banks in Bangalore, such as the Canara Bank, stated that the maximum life of computers in their various branches is 5 years. A respondent at the State Bank of Mysore revealed that the dumping tendency is more in the public sector banks as compared to their private sector counterparts because of the popular negligence among the citizens towards public resources in the country. Consequently, minimal efforts are being undertaken to repair the faulty parts of the EEEs and the out-of-use EEEs almost immediately find their way to the store house situated at the bank's premise. This store house acts as a large base of obsolete computers waiting the disposal procedure such as passing of tenders and auctions.

However, a premier educational institute in the country, Indian Institute of Management, Bangalore (IIM-B), affirmed that they always try their best to repair their faulty electronics in order to maximize the lifespan. This kind of behaviour by a bulk consumer could be considered as a positive state of affair in the current E-waste management regime in the country. Nevertheless, it has been observed that electronics such as mobile phones and computers are discarded while still very much in their useful life. This signifies a gradually declining lifespan of EEEs at each of the sectors considered. Once discarded, all these EEEs contribute to the E-waste stream of the country.

It has been observed that 'auction' is the most preferred measure to get rid of the obsolete electronics in both the banking sector and educational institutes. For instance, there is no significant difference between E-waste disposal practices among public, private and corporate banks and all abide by the rules of auction to manage their E-waste. While passing the tenders, only E-waste recyclers authorized by the Karnataka State Pollution Control Board are called for bidding. Karnataka Bank was the only bank which showed genuine interest in providing relevant information on their E-waste disposal practices and said that they follow a strict buy-back policy. With their dealer Wipro, they have an agreement which says that Wipro should replace their older computers, while the bank purchases new computers from the company. However, computer peripherals such as printers do not come under this buy-back policy. Therefore, the bank has to discard the printers through scrap dealers at certain price. IIM-B declares that it obtains certificates from the recyclers regarding eco-friendly disposal of the E-waste produced in their campus.

On a positive note, IIM-B has taken a number of commendable initiatives towards managing their E-waste. For instance, a start-up named 'Binbag' was incubated at NS Raghavan Center for Entrepreneurial Learning (NSRCEL) at IIM, Bangalore, in 2014. The motto of Binbag is 'Waste is a resource-only when treated the right way; treated wrongly it is an environmental burden'. Under the leadership of founder Mr. Achitra Borgohain, the start-up currently deals with all kinds of E-waste together with paper and plastic waste. The business model of Binbag is based on three pillars-awareness, access and assets (in the form of physical infrastructure or recycling facilities). The company essentially works with an aim to fill up the gap between the NGOs and recyclers. During our conversation with Mr. Borgohain, we were informed that Binbag has aided in recycling of approximately 12 tonnes of E-waste and has provided its service to 4000 customers in the city of Bangalore as of June 2016. He further stated that some customers have even provided $10-12 \mathrm{~kg}$ of waste per capita. Recently, the company has shifted its focus to 'bulk consumers' of EEEs and stopped picking up products from individual consumers. The start-up has already been attracting major global attention and Mr. Borgohain shared with us the experience of the company being covered in national and international media such as BBC News, ${ }^{6}$ The $\mathrm{Hindu}^{7}$ and Business Insider. Further, he has been invited as a speaker in several global platforms including United Nations Economic and Social Commission for Asia and the Pacific (UNESCAP) in June 2016.

Many branches of several public and private sector banks complained about obsolete computers and peripherals lying unattended for several years awaiting tender calls. Usually, an annual maintenance contract (AMC) is maintained with the dealer who looks after the computers during and after the warranty period. However, the period for which these EEEs are maintained after the warranty period is gradually decreasing because of preferences to purchase new EEEs instead of repairing or modifying the old ones. Unlike Wipro and IIM-B, most of the banks

\footnotetext{
${ }^{6}$ See: http://www.bbc.com/news/business-32339196.

7 See: http://www.thehindu.com/news/cities/bangalore/startup-offersgifts-in-exchange-for-etrash/article6473587.ece.
} 
considered for our study purpose were observed to be ignorant about the disposal procedure followed by the recycling agencies. Here, an 'Out of Sight, Out of Mind' kind of an attitude was seemed to be largely prevalent.

\section{Conclusion}

During the initial years of economic liberalization and IT revolution in India, E-waste registered a significant growth. It is particularly true for the last one decade. Today, E-waste management is a challenging task especially in major Indian cities. As a rapidly emerging city and India's largest IT hub, Bangalore is no exception. Bangalore produces considerable amount of E-waste from the IT and electronics companies, banking sector and educational institutes present in the city. Thus, the city figures prominently in domestic generation of E-waste through its bulk E-waste producers. Moreover, with a large literate population of around $88 \%$, the penetration of EEEs in Bangalore households could expected to be higher than that of many other Indian cities. Thus, the city is an E-waste hub of India, ranked third among the E-waste generating cities in the country as per government report.

In the city of Bangalore, we find that the bulk consumers like IT and electronic companies, banks and academic institutes adopt two different approaches to comply with the new EPR guidelines as per the E-waste (Management) Rules, 2016. These are: (1) IT companies like Wipro adopts a 'take-back system' where it is responsible for taking back the products originally produced in its various facilities from consumers; (2) most of the banks and educational institutes take 'auction' as the measure by calling tenders from authorized E-waste recyclers with one bank embracing an 'E-waste exchange system', or complying through producer responsibility organizations (PROs) towards responsible E-waste management in the city. Nevertheless, auction is still practiced by a number of IT companies through state and central pollution control board's authorized recyclers.

Nonetheless, E-waste management initiatives in the city are still inadequate and require major infrastructural and administrative considerations. For instance, most of the banks included in our study provided a disappointing picture towards their E-waste management systems. Either they are reluctant to provide any relevant information or mentioned 'auction' as the only key measure that they adopt towards disposal of their obsolete EEEs through registered recyclers. Beyond that, most of the banks are oblivious of responsible E-waste disposal. A public sector bank representative even complained that the throwaway tendency is more in these banks because of the omnipresent lackadaisical attitude towards public properties in the country. Awaiting tender calls, large volumes of E-waste are lying redundant in several banks. The attempts to repair old EEEs are almost absent because today, consumers believe that it is wiser to purchase a new device with a warranty period rather than repairing or modifying older EEEs. This leads to rapid obsolescence of EEEs while still in their useful lives.

The global electronics major considered for our study purpose reflects the issues concerning 'trial' mobile phones and other EEEs which are destroyed in bulks after testing. Such disposal practices call for thoughtful and innovative initiatives for sustainable E-waste management. On a positive note, leading IT companies in India like Wipro takes up some commendable initiatives towards responsible disposal of their E-waste. The company keeps tracks of their obsolete EEEs not only during the disposal procedures within the company, but also after their E-waste reaches the end of the recyclers by seeking proof of the disposal procedures that the recyclers have claimed to adopt. Similarly, IIT-B mentioned that they always try to maximize the life of their EEEs. Therefore, instead of throwing their non-functional EEEs right away, the preferred practice is to get them repaired or modified to the extent possible. Nevertheless, the lifespan of different EEEs varies from sector to sector. On a positive note, IIT-B has incubated a start-up for initiating responsible E-waste management practices in the city and the effort, till date, has been a success with huge volume of E-waste collected and national/international recognition received.

Nonetheless, a lack of transparency was observed in all the sectors towards providing relevant information on their E-waste management practices. Due to unavailability of adequate information from a number of IT and electronics company, banks and educational institutes, it is very difficult to estimate the exact amount of E-waste generated and available for recycling. We argue that if such ambiguity persists across these bulk producers of E-waste, it is rather intricate to formulate effective E-waste management strategies and policy initiatives for the city. A transparent system across diverse sectors with adequate infrastructural provisions and administrative control is one of the key measures to address Bangalore's E-waste apprehensions.

Acknowledgements The authors are grateful to Jawaharlal Nehru University, New Delhi, and Indian Council for Social Science Research (ICSSR), New Delhi, for the financial support provided.

\section{References}

Alsheyab MAT (2015) Potential recovery of precious metals from waste laptops in Jordan. Rare Met 34(7):517-521

Awasthi AK, Zeng XL, Li JH (2016a) Comparative examining and analysis of E-waste recycling in typical developing and developed countries. Procedia Environ Sci 35:676-680 
Awasthi AK, Zeng XL, Li JH (2016b) Environmental pollution of electronic waste recycling in India: a critical review. Environ Pollut 211:259-270

Awasthi AK, Zeng XL, Li JH (2016c) Relationship between e-waste recycling and human health risk in India: a critical review. Environ Sci Pollut Res 23(12):11509-11532

Borthakur A (2014) Generation and management of electronic waste in the city of Pune, India. Bull Sci Technol Soc 34(1-2):43-52

Borthakur A (2015) Generation and management of electronic waste in India: an Assessment from stakeholders' perspective. J Dev Soc 31(2):220-248

Borthakur A, Singh P (2016) E-waste in the era of a digitally empowered India: a real challenge (A glance at the world). Waste Manag 58:II

Borthakur A, Govind M (2017) Emerging trends in consumers' E-waste disposal behaviour and awareness: a worldwide overview with special focus on India. Resour Conserv Recycl 117(B):102-113

Borthakur A, Singh P (2017) Researches on informal E-waste recycling sector: it's time for a 'Lab to Land' approach. J Hazard Mater 323:730-732

Davis JM, Garb Y (2015) A model for partnering with the informal e-waste industry: rationale, principles and a case study. Resour Conserv Recycl 105:73-83

Dwivedy M, Suchde P, Mittal RK (2015) Modeling and assessment of e-waste take-back strategies in India. Resour Conserv Recycl 96:11-18

Garlapati VK (2016) E-waste in India and developed countries: management, recycling, business and biotechnological initiatives. Renew Sustain Energy Rev 54:874-881

Ghosh SK, Debnath B, Baidya R, De D, Li JH, Ghosh SK, Zheng LX, Awasthi AK, Liubarskaia MA, Ogola JS, Tavares AN (2016) Waste electrical and electronic equipment management and Basel Convention compliance in Brazil, Russia, India, China and South Africa (BRICS) nations. Waste Manag Res 34(8):693-707

Kannan D, Govindan K, Shankar M (2016) Formalize recycling of electronic waste. Nature 530(7590):281-281

Li JH, Zeng XL, Chen MJ, Ogunseitan OA, Stevels A (2015) ControlAlt-Delete: rebooting solutions for the E-waste problem. Environ Sci Technol 49(12):7095-7108

MAIT (2016). Salient Features of the E-Waste (Management) Rules, 2016 and its likely implication. http://www.mait.com/assets/ india-weee-rev—salient-features.pdf. Last accessed on: 15th Jan 2017

MoEF (2008) Guidelines for environmentally sound management of e-waste (as approved vide Ministry of Environment and Forests (MoEF)) (letter No. 23-23/2007-HSMD) dated March 12, 2008. Available on http://www.moef.nic.in/divisions/hsmd/guidelinese-waste.pdf. Accessed 20 May 2017

MoEF (2016). E-Waste (Management) Rules, 2016. http://www. moef.gov.in/sites/default/files/EWM\%20Rules\%202016\%20eng lish\%2023.03.2016.pdf. Last accessed on: 15th Jan 2017
Morris A, Metternicht G (2016) Assessing effectiveness of WEEE management policy in Australia. J Environ Manag 181:218-230

Needhidasan S, Samuel M, Chidambaram R (2014) Electronic waste-an emerging threat to the environment of urban India. J Environ Health Sci Eng 12:36

Pandey P, Govind M (2014) Social repercussions of e-waste management in India: a study of three informal recycling sites in Delhi. Int J Environ Stud 71(3):241-260

Parthasarathy B, Aoyama Y (2006) From software services to R\&D services: local entrepreneurship in the software industry in Bangalore, India. Environ Plan A 38(7):1269-1285

Patibandla M, Petersen B (2002) Role of transnational corporations in the evolution of a high-tech industry: the case of India's software industry. World Dev 30(9):1561-1577

Ramachandra TV, Varghese SK (2004) Environmentally sound options for e-wastes management. Envis Journal of Human Settlement. Retrieved from http://wgbis.ces.iisc.ernet.in/energy/ chapter/ewaste/ewaste.html. Accessed 20 May 2017

Reeves S, Kuper A, Hodges BD (2008) Qualitative researchQualitative research methodologies: ethnography. $\mathrm{Br}$ Med $\mathrm{J}$ 337(7668):512-514

Sharma R (2005) Building on a strong base. Frontline 22(21). Available on http://www.frontline.in/static/html/fl2221/stories/ 20051021002509200.htm. Accessed 25 May 2017

Tran PH, Wang F, Dewulf J, Huynh TH, Schaubroeck T (2016) Estimation of the unregistered inflow of electrical and electronic equipment to a domestic market: a case study on televisions in Vietnam. Environ Sci Technol 50(5):2424-2433

Van Eygen E, De Meester S, Tran HP, Dewulf J (2016) Resource savings by urban mining: the case of desktop and laptop computers in Belgium. Resour Conserv Recycl 107:53-64

Widmer R, Oswald-Krapf H, Sinha-Khetriwal D, Schnellmann M, Boni H (2005) Global perspectives on e-waste. Environ Impact Assess Rev 25(5):436-458

Yadav V, Karmakar S, Dikshit AK, Vanjari S (2016) A feasibility study for the locations of waste transfer stations in urban centers: a case study on the city of Nashik, India. J Clean Prod 126:191-205

Zeng XL, Li JH (2016) Measuring the recyclability of e-waste: an innovative method and its implications. J Clean Prod 131:156-162

Zeng X, Duan H, Wang F, Li J (2016a). Examining environmental management of e-waste: China's experience and lessons. Renew Sustain Energy Rev 72:1076-1082

Zeng XL, Gong RY, Chen WQ, Li JH (2016b) Uncovering the recycling potential of "New" WEEE in China. Environ Sci Technol 50(3):1347-1358

Zeng XL, Yang CR, Chiang JF, Li JH (2017) Innovating e-waste management: from macroscopic to microscopic scales. Sci Total Environ 575:1-5 